\title{
Synthesis of a Calix[4]arene-monodiazonium Salt for Surface Modification
}

\author{
Volodymyr Malytskyi, ${ }^{[a]}$ Ludovic Troian-Gautier, ${ }^{[a]}$ Alice Mattiuzzi, ${ }^{[a],[b]}$ Sarah Lambotte, ${ }^{[a]}$ Benedetta \\ Cornelio, ${ }^{[a]}$ Corinne Lagrost, ${ }^{*[c]}$ and Ivan Jabin ${ }^{*[a]}$
}

\begin{abstract}
Reduction of calix[4]arene-tetradiazonium salts at the vicinity of a surface, notably carbon surfaces, leads to the formation of a dense and robust covalently-bound monolayer. To expand the versatility of this unique methodology, the efficient synthesis of a calix[4]arene bearing a single diazonium group and thus a single anchoring point was achieved. The introduction of the diazonium group was developed through an original approach involving a copper-catalyzed reaction for the preparation of an intermediate azido-calixarene. The grafting ability of the calix[4]arenemonodiazonium cation was evaluated by investigating its electrochemical reduction at glassy carbon electrodes. Studies of the blocking properties of the modified surfaces toward redox probes evidenced the formation of compact covalently-bound layers at the carbon substrates, opening interesting perspectives in the field of surface modification by calixarene-based diazonium salts.
\end{abstract}

\section{Introduction}

Surface modification is an ever-growing field of research that aims at designing surfaces with tailored properties such as wettability, hydrophobicity, biocompatibility, corrosion resistance, reactivity, stimuli-responsivity, etc. In this context, one of the challenges faced by chemists is the development of general methods for the grafting of compact, robust and well-organized organic monolayers that can be readily post-functionalized. ${ }^{[1]}$ Such sophisticated interfaces can find applications, for instance, in the field of sensing or biosensing notably when a recognition system (e.g. an antibody, an artificial receptor, etc.) is anchored at the post-functionalization step. ${ }^{[2]}$ Self-assembled monolayers (SAMs) can be obtained through the well-known method that consists in the chemisorption of thiol derivatives. ${ }^{[3]}$ However, this strategy presents several drawbacks: (i) it is restricted to the modification of metallic surfaces such as gold, platinum or copper, (ii) the dynamic nature of the thiol-metal bond leads to lack of thermal

[a] Dr. V. Malytskyi, Dr. L. Troian-Gautier, Dr. A. Mattiuzzi, S. Lambotte, Dr. B. Cornelio and Prof. I. Jabin

Laboratoire de Chimie Organique, Université Libre de Bruxelles (ULB), avenue F. D. Roosevelt 50, CP160/06, B-1050 Brussels, Belgium.

E-mail: jjabin@ulb.ac.be http://chimorg.ulb.ac.be/

[b] Dr. A. Mattiuzzi

X4C, Rue Chêne Bonnet 128, 6110 Montigny-le-Tilleul, Belgium

[c] Dr. C. Lagrost

Univ. Rennes, Institut des Sciences Chimiques de Rennes -UMR 6226, Campus de Beaulieu, 35042 Rennes Cedex, France.

E-mail: corinne.lagrost@univ-rennes1.fr

https://iscr.univ-rennes $1 . f r /$

Supporting information for this article is given via a link at the end of the document and long-term stability of the grafted layers, (iii) it is difficult to achieve a control over the composition of mixed monolayers and (iv) the possible oxidation of thiol derivatives or their reductive desorption at cathodic potentials limit their use in the field of electrochemical sensing. ${ }^{[4]}$ Alternatively, highly stable organic layers can be covalently grafted on a wide variety of surfaces through the reduction of aryl diazonium salts. ${ }^{[5]}$ This grafting strategy leads, however, to the formation of disordered multilayers as the in situ generated aryl radicals can also react with the already grafted aryl layers. ${ }^{[6]}$ To circumvent this problem we have described a new approach using calix[4]arenetetradiazonium salts (Figure 1, compounds $\mathbf{X}_{4} \mathbf{N}_{4}$ ). ${ }^{[7]}$ It was indeed shown that these compounds provide compact and highly stable monolayers thanks to their unique macrocyclic structure. To preclude the formation of multilayers, a key prerequisite is to block the calix[4]arene backbone into its cone conformation. For this, the $R$ substituents at the small rim must be at least as bulky as propyl groups ${ }^{[8]}$ to prevent the oxygen-through-the-annulus rotation of the aromatic units. Besides, when $\mathrm{R}$ contains a functional group such as $\mathrm{COOH}$, a post-functionalization of the surface can be readily achieved under mild conditions. Calix[4]arene-tetradiazonium salts were notably used for the modification and further post-functionalization of gold, carbon and germanium surfaces, ${ }^{[7,9]}$ but also polymers ${ }^{[10]}$ and nanomaterials such as gold nanoparticles. ${ }^{[11]}$ Furthermore, this method allows for controlling the composition of binary mixed monolayers, which is essential for sensing applications. ${ }^{[12,13]}$ All in all, calix[4]arenetetradiazonium salts represent nowadays an established class of compounds that can find various applications in the field of surface modification. ${ }^{[14]}$ In order to enlarge this family of compounds as well as to gain insights into the factors that govern this calixarene-based coating methodology, we wanted to investigate the grafting of a calix[4]arene bearing a single diazonium group. Indeed, such a calix[4]arene-monodiazonium salt would allow us to evaluate the influence of the number of anchoring points on the robustness and compactness of the grafted layer. Moreover, the number of anchoring points may also influence the 3D conformation of the calixarene once anchored onto the surface. In addition, if a single anchoring point per calixarene could have no impact on the surface coverage, it should however reduce significantly the chemical modification of the surface. It is noteworthy that the immobilization of a calix[6]arene-monodiazonium salt was recently developed with the aim of designing an electrochemical sensor for uranyl. ${ }^{[15]}$ However, this compound was not conformationally blocked, preventing a priori any control on the vertical extension of the grafting.

Herein, we report on the synthesis and immobilization of calix[4]arene-monodiazonium salt 1 (Figure 1). Grafting experiments on glassy carbon (GC) electrodes were undertaken in order to evaluate the grafting properties of this new compound. 

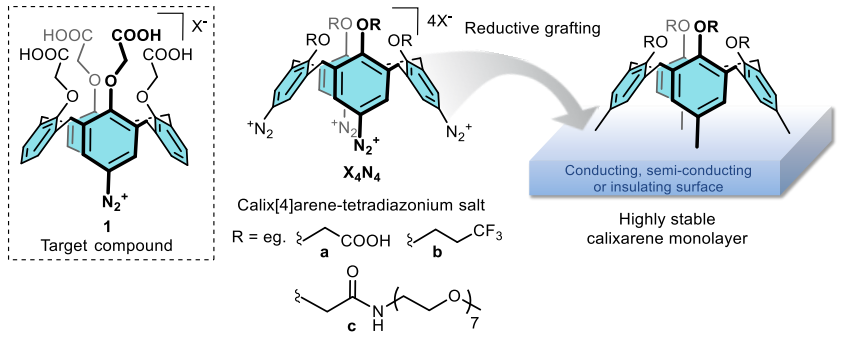

Figure 1. Surface modification with calix[4]arene-tetradiazonium salts $\mathbf{X}_{4} \mathbf{N}_{4}$ ac. ${ }^{[7,9-13]}$ Inset: targeted calix[4]arene-monodiazonium salt 1 . Note that the representation of the grafted calixarene does not necessarily imply that the four aryl units are linked to the surface.

\section{Results and Discussion}

Synthesis and characterization of calix[4]arenemonodiazonium salt 1 . The synthesis of a calix[4]arenemonodiazonium salt bearing four carboxylato appending arms (i.e. 1) was envisaged in order i) to compare its grafting properties with those of the closely related tetracarboxylato-tetradiazonium salt $\mathbf{X}_{4} \mathbf{N}_{4} \mathbf{a}$, ii) to permit a post-functionalization of the calixarenecoated surface. Selective monofunctionalization of the large rim was required for the synthesis of the target compound 1 . To achieve this goal, a classical strategy consists in transferring the functionalization pattern of the small rim to the large rim. ${ }^{[16,17]}$ The known calix[4]arene-trisester $3^{[18]}$ appeared to be a suitable candidate for this strategy as its single phenolic unit can be selectively modified through an electrophilic aromatic substitution. Compound $\mathbf{3}$ was thus prepared through the iteroselective ${ }^{[19]}$ alkylation of calix[4]arene 2 with ethylbromoacetate in the presence of $\mathrm{CaH}_{2}$ (Scheme 1). Selective mono-nitration of 3 at the para-position of the phenolic ring was already described in a moderate $56 \%$ yield. ${ }^{[20]}$ Our attempts to reproduce this protocol using a mixture of $\mathrm{HNO}_{3}(70 \%)$ and glacial acetic acid in dichloromethane were however unsuccessful. A complex mixture of products was indeed obtained even when the reaction was carried out under milder nitration conditions (i.e. $\mathrm{KNO}_{3} / \mathrm{AlCl}_{3}$ in acetonitrile at $0^{\circ} \mathrm{C}$ or $\mathrm{NaNO}_{2}$ in trifluoroacetic acid at room temperature). In all cases, ESI-MS analysis of the crude reaction mixture showed the presence of a product at $\mathrm{m} / \mathrm{z} 719$ Th that would result from the oxidation of the phenolic ring into a quinone unit. ${ }^{[21]}$ Further evidence of quinone formation came from the presence of a strong infrared band at $1714 \mathrm{~cm}^{-1}$ in the IR spectrum of the crude reaction mixtures. Note that direct mononitration of calix[4]arene-tetraester or calix[4]arene-tetraacid using different mixtures of $\mathrm{HNO}_{3}$ and glacial acetic acid was also attempted but complex mixtures of polynitro products were obtained. As a result, an alternative route consisting in the introduction of an azido group through copper-catalysis ${ }^{[22]}$ was investigated. First, selective bromination of compound 3 using $\mathrm{Br}_{2}$ in chloroform at $0^{\circ} \mathrm{C}$ afforded the corresponding mono-bromo derivative 4 in high yield. Subsequent alkylation of the unsubstituted phenol moiety using ethylbromoacetate in THF in the presence of sodium hydride led to the tetra-ester derivative 5 in $89 \%$ yield. Note that a single ${ }^{13} \mathrm{C}$ signal at $31.5 \mathrm{ppm}$ is observed for the four $\mathrm{ArCH}_{2} \mathrm{Ar}$ methylenic carbon atoms of $\mathbf{5}$. According to the "de Mendoza rule", ${ }^{[23]}$ this value is consistent with a syn relationship between all the aromatic units, indicating that the calixarene scaffold is constrained in the cone conformation. Calix[4]arene-tetraestermonobromide 5 was then engaged in a copper-catalyzed transformation using copper iodide, trans- $N, N$ dimethylcyclohexane-1,2-diamine, sodium azide and sodium ascorbate in a 7:3 mixture of $\mathrm{EtOH} / \mathrm{H}_{2} \mathrm{O}$. To our delight, the desired mono-azido derivative 6 was obtained in $72 \%$ yield after flash chromatography purification. The presence of the azido group is ascertained by IR spectroscopy through an intense band at $v_{(\mathrm{N} 3)}=2109 \mathrm{~cm}^{-1}$. Moreover, the ${ }^{1} \mathrm{H}$ NMR spectrum of 6 shows a singlet at $6.08 \mathrm{ppm}$ integrating for two protons, which is in good accordance with the presence of an aromatic unit bearing an azido group. To our knowledge, this is the first time that such a copper-catalyzed reaction is used for the introduction of an azido group on a calixarene. This strategy appears as a valuable alternative to the routes that are classically described for the preparation of azido-calixarenes. Indeed, these routes often involve a sequence of nitration and subsequent reduction of the nitro group followed by diazotisation of the aniline and substitution with azide. ${ }^{[24]}$ Hydrolysis of the ester groups of 6 yielded the tetraacid $\mathbf{7}$ in high yield and a Staudinger reduction of the azido group gave the corresponding amino derivative $\mathbf{8}$. It is noteworthy that compound $\mathbf{8}$ was already described in the literature ${ }^{[20]}$ but it was obtained in a lower $28 \%$ overall yield from tris-ester 3 (42\% in our case) through a different synthesis that involved the sensitive nitration of $\mathbf{3}$. Finally, target mono-diazonium salt $\mathbf{1}$ was obtained in high yield by treating $\mathbf{8}$ with nitrosonium tetrafluoroborate at low temperature in acetonitrile.

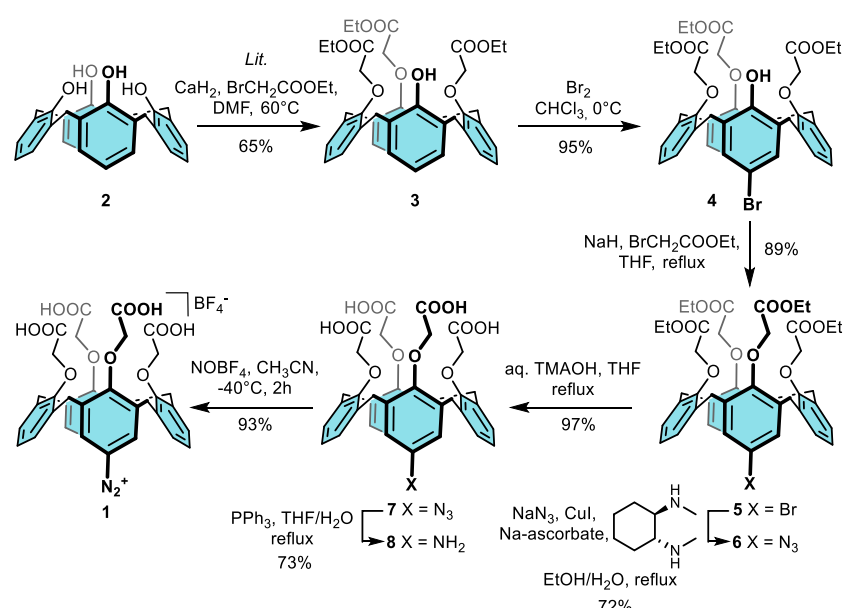

Scheme 1. Synthesis of calix[4]arene-monodiazonium salt 1.

Calix[4]arene-monodiazonium salt $\mathbf{1}$ was unambiguously characterized by IR $\left(v_{(\mathrm{N} 2+)}=2258 \mathrm{~cm}^{-1}\right)$ and ${ }^{1} \mathrm{H}$ NMR spectroscopies. HRMS analysis was not performed due to the low stability of diazonium salts against temperature. 

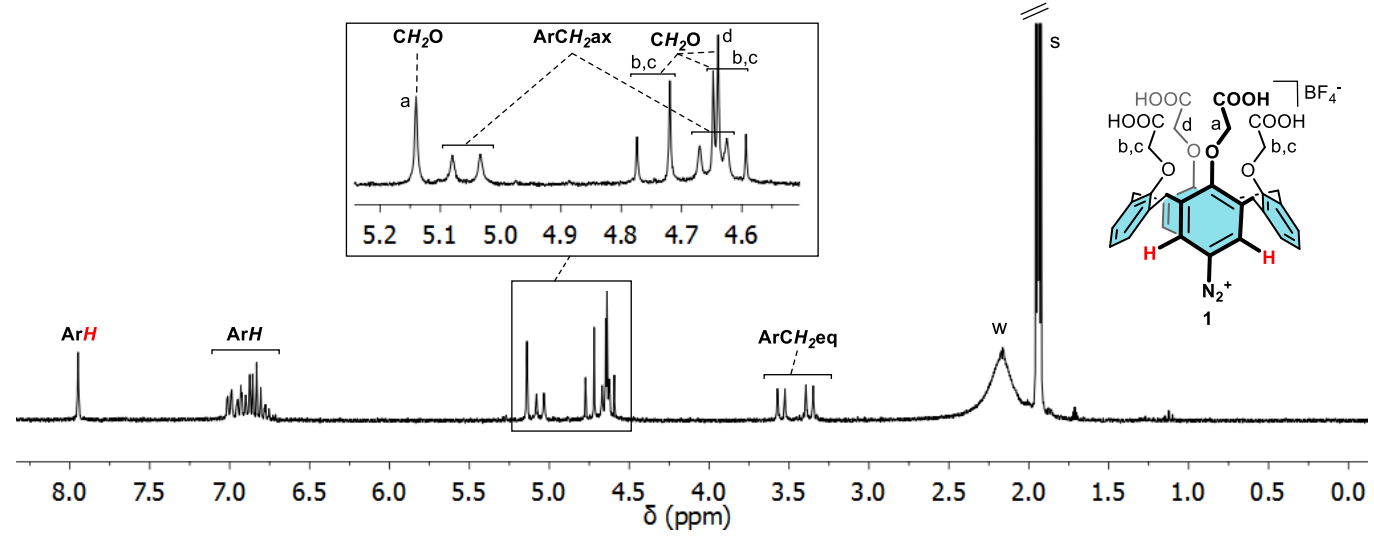

Figure 2. ${ }^{1} \mathrm{H}$ NMR $(298 \mathrm{~K}, 300 \mathrm{MHz})$ spectrum of calix[4]arene-monodiazonium salt 1 in $\mathrm{CD}_{3} \mathrm{CN}$; w: water, s: solvent.

The ${ }^{1} \mathrm{H}$ NMR spectrum of 1 is characteristic of a calix[4]arene possessing a $C_{\mathrm{s}}$ symmetry (Figure 2): i.e. two doublets for both the $\mathrm{ArCH}_{2}$ ax and $\mathrm{ArCH}_{2}$ eq protons, two singlets for the $\mathrm{CH}_{2} \mathrm{O}_{\mathrm{a}, \mathrm{d}}$ protons and two doublets for the diastereotopic $\mathrm{CH}_{2} \mathrm{O}_{\mathrm{b}, \mathrm{c}}$ protons. Besides, the singlet at $7.95 \mathrm{ppm}$ clearly attests of the presence of an aromatic ring bearing an electron withdrawing group. Very interestingly, diazonium salt 1 was stored for several weeks in a fridge without any trace of degradation. With the synthesis of calix[4]arene-monodiazonium salt 1 successfully developed, we then investigated its grafting ability.

Electrografting of calix[4]arene-monodiazonium salt 1 onto glassy carbon surface. The electrochemical reduction of 1 in acetonitrile containing $0.1 \mathrm{M} \mathrm{NBu}_{4} \mathrm{PF}_{6}$ as supporting salts was examined by cyclic voltammetry on a glassy carbon (GC) electrode (Figure 3A). We observed the characteristic behaviour of the electroreduction of aryldiazonium cations when the potential is swept between $0.6 \mathrm{~V}$ and $-0.6 \mathrm{~V}$ versus saturated calomel electrode (SCE). ${ }^{[25]} \mathrm{A}$ broad irreversible and ill-defined single reduction peak was indeed obtained at about $-0.3 \mathrm{~V}$ vs SCE during the first scan, then the current intensity was strongly attenuated in the following electrochemical cycles. The peak corresponds to the reduction of diazonium cations into phenyl radicals formed upon $\mathrm{N}_{2}$ release. It is noteworthy that a similar broad reduction peak was obtained for the electrochemical reduction of calix[4]arene-tetradiazonium salts. ${ }^{[12]}$ The electrochemically-formed phenyl radicals then react with the electrode surface, leading to a covalently bound blocking layer at the electrode surface. The reduction of calix[4]arenemonodiazonium salt 1 was also performed by chronoamperometry at a constant potential of $-0.5 \mathrm{~V}$ vs SCE for 5 min. In that case, the chronoamperogram also exhibited the expected behaviour for electrografting as indicated by the sudden drop of current a few seconds after holding the potential (Figure 3B).
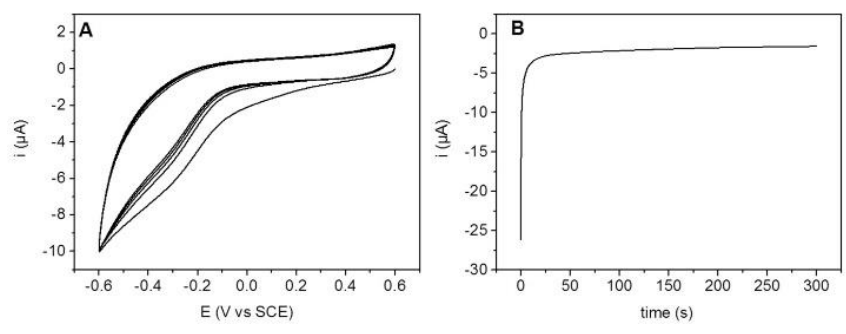

Figure 3. Electrochemical behaviour of $1 \mathrm{mM}$ calix[4]arene-monodiazonium salt 1 in an acetonitrile solution containing $0.1 \mathrm{M} \mathrm{NBu}_{4} \mathrm{PF}_{6}$ at a $\mathrm{GC}$ disk electrode $\left(0.07 \mathrm{~cm}^{2}\right)$. A) cyclic voltammetry at $0.1 \mathrm{~V} / \mathrm{s}$. B) Chronoamperometry at a fixed potential equal to $-0.5 \mathrm{~V}$ vs SCE.

The modified surfaces were then copiously rinsed with a series of solvents (acetonitrile, ethanol, water) to remove any residual nongrafted calixarenes and dried with a stream of argon. The charge transfer properties of the as-modified electrodes were then characterized in aqueous solutions containing potassium ferricyanide $\left(\mathrm{K}_{3} \mathrm{Fe}(\mathrm{CN})_{6}\right)$ or dopamine as redox probes and the results were compared to those obtained with $\mathrm{GC}$ electrodes modified with calix[4]arene-tetradiazonium $\mathbf{X}_{4} \mathrm{~N}_{4} \mathbf{a}$. The study of the blocking properties of modified carbon surfaces toward these redox probes is classically employed to demonstrate the presence of a grafted layer. ${ }^{[1,3,5]}$ It also allows for an indirect evaluation of the layer compactness. Indeed, in cyclic voltammetry the blocking properties can be easily evidenced through a larger peak-to-peak separation along with a dramatic decrease of the current intensity. The grafted layer at the electrode acts as an insulating barrier that slows down the electronic transfer kinetics between redox probes and the electrode. Figures 4A-D shows typical voltammograms in the presence of dopamine or potassium ferricyanide obtained at bare and calixarene-coated glassy carbon electrodes. Compared to the reversible redox processes obtained at the bare electrode, a strong inhibition of the electrochemical response was evidenced 
for all the modified electrodes. This clearly indicates that an organic layer was formed at the electrode surface upon electrochemical reduction of 1 . Dopamine in acidic medium is a particularly sensitive probe because its oxidation to the corresponding o-quinone requires adsorption onto the carbon surface to occur. Dopamine oxidation is therefore used as a specific tool to detect pinholes/defects/empty spaces within a layer. ${ }^{[26]}$ Remarkably, the dopamine oxidation is hardly detected in the case of electrodes modified by calixarene 1. As observed in Figure 4, the blocking properties towards the two redox probes are fully similar for layers prepared with $\mathbf{1}$ and its parent calix[4]arene-tetradiazonium $\mathbf{X}_{4} \mathbf{N}_{4} \mathbf{a}$, under the same experimental conditions. Further analyses are currently performed to investigate the organization and structuring of the different layers at the molecular scale and will be reported elsewhere.
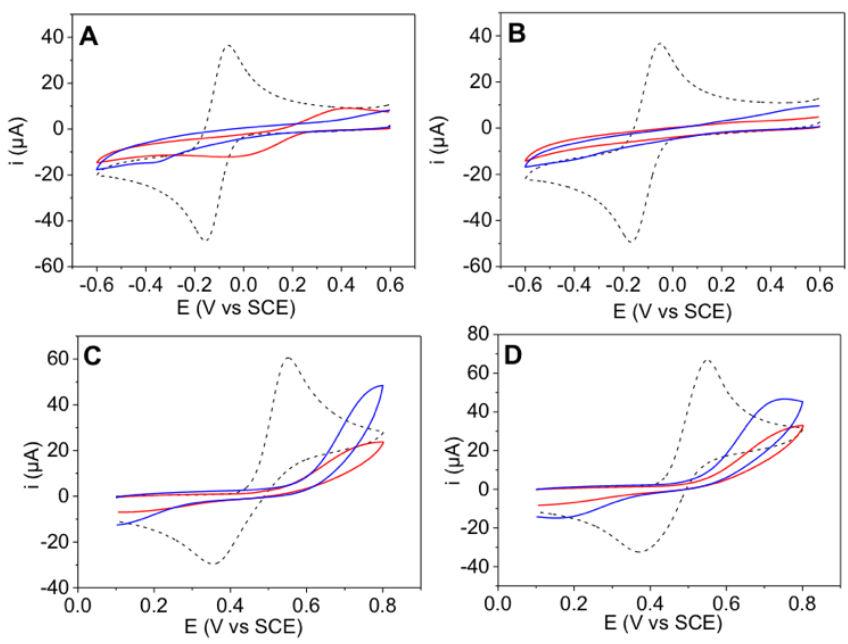

Figure 4. Cyclic voltammetry at glassy carbon electrodes of $1 \mathrm{mM}$ potassium ferricyanide in aqueous $0.1 \mathrm{M} \mathrm{KCl}(\mathrm{A}-\mathrm{B})$ and of $2 \mathrm{mM}$ dopamine in aqueous $0.1 \mathrm{M}$ $\mathrm{H}_{2} \mathrm{SO}_{4}$ (C-D) before (dashed lines) and after (solid lines) electrografting of calixarene (red) and calix[4]arene-tetradiazonium salt $\mathbf{X}_{\mathbf{4}} \mathbf{N}_{\mathbf{4}} \mathbf{a}$ (blue) through cyclic voltammetry (A,C) or through chronoamperometry (B,D). Scan rate is $0.2 \mathrm{~V} \mathrm{~s}^{-1}$

\section{Conclusions}

The efficient synthesis of a calix[4]arene bearing a single diazonium group on the large rim (i.e. 1) was achieved in high yields. For the introduction of the diazonium group, a unique strategy that involves the preparation of an intermediate azidocalixarene through a copper-catalyzed reaction was developed in order to avoid the classical and sensitive nitration step. Calix[4]arene-monodiazonium salt $\mathbf{1}$ can be easily electrografted within a few minutes on GC electrodes by cyclic voltammetry or chronoamperometry. The study of the blocking properties of the calixarene-coated electrodes toward redox probes revealed that compact layers were formed upon electrografting of $\mathbf{1}$. In other words, monodiazonium salt 1 displays similar grafting ability than the previously described calix[4]arene-tetradiazonium salts while being immobilized by a single anchoring point.

\section{Experimental Section}

General experimental methods. Solvents were distilled prior to use Anhydrous THF was obtained through distillation over sodium and benzophenone under argon; all the other anhydrous solvents were purchased. Silica gel (230-400 mesh) was used for flash chromatography. ${ }^{1} \mathrm{H}$ NMR spectra were recorded either at 300 or $400 \mathrm{MHz} .{ }^{13} \mathrm{C}$ NMR spectra were recorded at $100 \mathrm{MHz}$. Traces of residual solvents were used as internal standards for ${ }^{1} \mathrm{H}$ and ${ }^{13} \mathrm{C}$ chemical shift referencing. Abbreviations: s: singlet, d: doublet, t: triplet, q: quadruplet, m: multiplet. 2D NMR spectra (COSY, HSQC) were recorded to complete signal assignments. High resolution mass spectra were recorded with a Q-TOF ESI spectrometer at the Analytical Platform of the Faculty of Pharmacy (ULB). Electrospray ionization (ESI) mass spectra were recorded with an ESI-MS apparatus equipped with an ion-trap. Melting points $(\mathrm{mp})$ are uncorrected. ATR-FTIR spectra were recorded at room temperature.

Caution! Although we have not encountered any problem, it is known that diazonium salts derivatives are potentially explosive and should be handled with appropriate precautions. The final product 1 has been synthesized in low quantity from its precursor directly prior to use.

Calix[4]arene-trisester 3. Calcium hydride $(2.56 \mathrm{~g}, 61 \mathrm{mmol})$ was added to a solution of calix[4]arene 2 (5.17 g, $12.2 \mathrm{mmol})$ in anhydrous DMF (50 $\mathrm{mL}$ ) under argon atmosphere. The mixture was stirred for $15 \mathrm{~min}$ at room temperature before ethyl bromoacetate $(16.8 \mathrm{~mL}, 152 \mathrm{mmol})$ was added. The mixture was heated to $60^{\circ} \mathrm{C}$ and stirred for 4 days under inert atmosphere. After cooling to room temperature, the solution was concentrated under reduced pressure and diluted with $50 \mathrm{~mL}$ of $\mathrm{CH}_{2} \mathrm{Cl}_{2}$. After the careful addition of $0.1 \mathrm{M} \mathrm{HCl}(40 \mathrm{~mL})$ at $0^{\circ} \mathrm{C}$, the product was extracted with $\mathrm{CH}_{2} \mathrm{Cl}_{2}(3 \times 100 \mathrm{~mL})$. The combined organic solutions were washed once with deionized water and concentrated under reduced pressure. The crude residue was purified by column chromatography over silica $\left[\mathrm{CH}_{2} \mathrm{Cl}_{2} / \mathrm{C}_{6} \mathrm{H}_{12} /\right.$ EtOAc $(6: 3.75: 0.25$ then $\left.6: 3.5: 0.5)\right]$ to yield the calix[4]arene-trisester 3 as a white solid $\left(5.44 \mathrm{~g}, 65 \%\right.$ yield). The ${ }^{1} \mathrm{H}$ NMR spectrum of $\mathbf{3}$ is in accordance with the one reported in the literature. ${ }^{[27]}$

Calix[4]arene-trisester-monobromide 4. Calix[4]arene-trisester 3 (3.06 $\mathrm{g}, 4.48 \mathrm{mmol})$ was dissolved in anhydrous $\mathrm{CHCl}_{3}(70 \mathrm{~mL})$ under argon atmosphere and the solution was cooled to $0^{\circ} \mathrm{C}$ in an ice bath. Bromine $(0.27 \mathrm{~mL}, 5.24 \mathrm{mmol})$ was added and the reaction mixture was stirred for 40 min at $0^{\circ} \mathrm{C}$. The mixture was then quenched with a saturated $\mathrm{Na}_{2} \mathrm{~S}_{2} \mathrm{O}_{3}$ aqueous solution $(50 \mathrm{~mL})$. The organic phase was separated and the aqueous phase was extracted with $\mathrm{CH}_{2} \mathrm{Cl}_{2}(3 \times 50 \mathrm{~mL})$. The combined organic phases were washed once with deionized water $(100 \mathrm{~mL})$ and concentrated under reduced pressure. The crude material was purified by column chromatography on silica $\left[\mathrm{CH}_{2} \mathrm{Cl}_{2} / \mathrm{C}_{6} \mathrm{H}_{12} / \mathrm{EtOAc}(6: 3.5: 0.5)\right]$ to afford the desired product 4 as a light-yellow solid (3.23 g, 95\% yield). Mp $=144^{\circ} \mathrm{C} . \mathrm{IR}(\mathrm{NaCl}) \vee\left(\mathrm{cm}^{-1}\right)=3467,1766,1735 .{ }^{1} \mathrm{H} \mathrm{NMR}\left(400 \mathrm{MHz}, \mathrm{CDCl}_{3}\right.$, $298 \mathrm{~K}): \delta(\mathrm{ppm})=7.12,(\mathrm{~s}, 2 \mathrm{H}, \mathrm{ArH}), 7.07\left(\mathrm{~d},{ }^{3} \mathrm{~J}=7.6 \mathrm{~Hz}, 2 \mathrm{H}, \mathrm{ArH}\right), 6.91(\mathrm{t}$, $\left.{ }^{3} \mathrm{~J}=7.6 \mathrm{~Hz}, 1 \mathrm{H}, \mathrm{ArH}\right), 6.45-6.65(\mathrm{~m}, 6 \mathrm{H}, \mathrm{ArH}), 6.40(\mathrm{~s}, 1 \mathrm{H}, \mathrm{OH}), 5.04(\mathrm{~s}$, $2 \mathrm{H}, \mathrm{OCH}_{2} \mathrm{COOEt}$ ), 4.91 (d, ${ }^{2} \mathrm{~J}=13.6 \mathrm{~Hz}, 2 \mathrm{H}, \mathrm{ArCH} 2 \mathrm{ax}$ ), 4.65 (d, ${ }^{2} \mathrm{~J}=15.6$ $\mathrm{Hz}, 2 \mathrm{H}, \mathrm{ArOCH}_{2} \mathrm{COOEt}$ ), 4.47 (d, ${ }^{2} \mathrm{~J}=15.6 \mathrm{~Hz}, 2 \mathrm{H}, \mathrm{ArOCH} \mathrm{COOEt}_{2} \mathrm{COO}, 36$ (d, ${ }^{2} \mathrm{~J}=13.6 \mathrm{~Hz}, 2 \mathrm{H}, \mathrm{ArCH} \mathrm{H}_{2} \mathrm{ax}$ ), 4.22-4.31 (q, ${ }^{3} \mathrm{~J}=7.2 \mathrm{~Hz}, 4 \mathrm{H}, \mathrm{OCH}_{2} \mathrm{CH}_{3}$ ), $4.14\left(\mathrm{q},{ }^{3} \mathrm{~J}=7.2 \mathrm{~Hz}, 2 \mathrm{H}, \mathrm{OCH}_{2} \mathrm{CH}_{3}\right), 3.31$ (d, ${ }^{2} \mathrm{~J}=13.6 \mathrm{~Hz}, 2 \mathrm{H}, \mathrm{ArCH}_{2} \mathrm{eq}$ ) $3.26\left(\mathrm{~d},{ }^{2} \mathrm{~J}=13.6 \mathrm{~Hz}, 2 \mathrm{H}, \mathrm{ArCH}_{2} \mathrm{eq}\right), 1.32\left(\mathrm{t},{ }^{3} \mathrm{~J}=7.2 \mathrm{~Hz}, 6 \mathrm{H}, \mathrm{COOCH}_{2} \mathrm{CH}_{3}\right)$, $1.26\left(\mathrm{t},{ }^{3} \mathrm{~J}=7.2 \mathrm{~Hz}, 3 \mathrm{H}, \mathrm{COOCH}_{2} \mathrm{CH}_{3}\right) .{ }^{13} \mathrm{C} \mathrm{NMR}\left(100 \mathrm{MHz}, \mathrm{CDCl}_{3}, 298\right.$ $\mathrm{K}): \delta(\mathrm{ppm})=170.9,169.5,155.7,154.2,152.6,135.8,133.5,132.3,131.4$, $130.9,129.6,128.9,128.5,124.2,123.5,110.6,72.2,70.4,61.2,60.5$, 31.9, 31.0, 29.8, 14.3. HRMS $(E S I+): ~ m / z$ calcd for $\mathrm{C}_{40} \mathrm{H}_{45} \mathrm{BrNO}_{10}$ $\left[\mathrm{M}+\mathrm{NH}_{4}\right]^{+}$: 778.2227; found: 778.2221 . 
Calix[4]arene-tetraester-monobromide 5 . Sodium hydride $(290 \mathrm{mg}$ $7.25 \mathrm{mmol}, 60 \%$ dispersion in mineral oil) was added to a solution of calix[4]arene-trisester $4(1.450 \mathrm{~g}, 1.90 \mathrm{mmol})$ in anhydrous THF $(30 \mathrm{~mL})$ under argon atmosphere. The mixture was stirred for $5 \mathrm{~min}$ at room temperature before ethyl bromoacetate $(0.87 \mathrm{~mL}, 7.87 \mathrm{mmol})$ was added. The mixture was further stirred at reflux overnight under inert atmosphere. After being cooled to room temperature, the solution was concentrated under reduced pressure. The resulting residue was dispersed in deionized water $(40 \mathrm{~mL})$ and extracted with $\mathrm{CH}_{2} \mathrm{Cl}_{2}(3 \times 50 \mathrm{~mL})$. The organic extracts were combined, washed once with deionized water and concentrated under reduced pressure. The crude product was purified by column chromatography over silica $\left[\mathrm{CH}_{2} \mathrm{Cl}_{2} / \mathrm{EtOH}\right.$ (99:1)] to yield product 5 as a white solid $\left(1.430 \mathrm{~g}, 89 \%\right.$ yield). $\mathrm{Mp}=102^{\circ} \mathrm{C}$. IR $(\mathrm{NaCl}) \vee\left(\mathrm{cm}^{-1}\right)=1747$, 1735. ${ }^{1} \mathrm{H}$ NMR $\left(400 \mathrm{MHz}, \mathrm{CDCl}_{3}, 298 \mathrm{~K}\right): \delta(\mathrm{ppm})=6.83-6.62(\mathrm{~m}, 7 \mathrm{H}, \mathrm{ArH})$, $6.59(\mathrm{~s}, 2 \mathrm{H}, \operatorname{ArH}), 6.50\left(\mathrm{~d},{ }^{3} \mathrm{~J}=7.2 \mathrm{~Hz}, 2 \mathrm{H}, \operatorname{ArH}\right), 4.86\left(\mathrm{~d},{ }^{2} \mathrm{~J}=14 \mathrm{~Hz}, 2 \mathrm{H}\right.$, $\left.\mathrm{ArCH}_{2} \mathrm{ax}\right), 4.85\left(\mathrm{~d},{ }^{2} \mathrm{~J}=13.6 \mathrm{~Hz}, 2 \mathrm{H}, \mathrm{ArCH}_{2} \mathrm{ax}\right), 4.76\left(\mathrm{~d}, 2 \mathrm{H},{ }^{2} \mathrm{~J}=16.4 \mathrm{~Hz}\right.$, $\left.\mathrm{ArOCH}_{2} \mathrm{CO}\right), 4.70\left(\mathrm{~d}, 2 \mathrm{H},{ }^{2} \mathrm{~J}=16.4 \mathrm{~Hz}, \mathrm{ArOCH}_{2} \mathrm{CO}\right), 4.66(\mathrm{~s}, 2 \mathrm{H}$, $\mathrm{ArOCH}_{2} \mathrm{CO}$ ), 4.65 (s, $2 \mathrm{H}, \mathrm{ArOCH}_{2} \mathrm{CO}$ ), $4.22\left(\mathrm{q},{ }^{3} \mathrm{~J}=7.2 \mathrm{~Hz}, 2 \mathrm{H}, \mathrm{OCH}_{2} \mathrm{CH}_{3}\right.$ ), $4.21\left(\mathrm{q},{ }^{3} \mathrm{~J}=7.2 \mathrm{~Hz}, 2 \mathrm{H}, \mathrm{OCH}_{2} \mathrm{CH}_{3}\right), 4.19\left(\mathrm{q},{ }^{3} \mathrm{~J}=7.2 \mathrm{~Hz}, 4 \mathrm{H}, \mathrm{COOCH}_{2} \mathrm{CH}_{3}\right.$ ), $3.26\left(\mathrm{~d},{ }^{2} \mathrm{~J}=14 \mathrm{~Hz}, 2 \mathrm{H}, \operatorname{ArCH} 2 \mathrm{eq}\right), 3.19$ (d, $\left.{ }^{2} \mathrm{~J}=14 \mathrm{~Hz}, 2 \mathrm{H}, \mathrm{ArCH}_{2} \mathrm{eq}\right), 1.30$ (t, $\left.{ }^{3} \mathrm{~J}=7.2 \mathrm{~Hz}, 3 \mathrm{H}, \mathrm{COOCH}_{2} \mathrm{CH}_{3}\right), 1.29\left(\mathrm{t},{ }^{3} \mathrm{~J}=7.2 \mathrm{~Hz}, 3 \mathrm{H}, \mathrm{COOCH}_{2} \mathrm{CH}_{3}\right)$, $1.28\left(\mathrm{t},{ }^{3} \mathrm{~J}=7.2 \mathrm{~Hz}, 6 \mathrm{H}, \mathrm{COOCH}_{2} \mathrm{CH}_{3}\right) .{ }^{13} \mathrm{C} \mathrm{NMR}\left(100 \mathrm{MHz}, \mathrm{CDCl}_{3}, 298 \mathrm{~K}\right)$ : $\delta(\mathrm{ppm})=170.3,170.1,169.9,156.4,155.7,155.0,136.7,135.3,134.5$, 134.2, 131.0, 129.3, 128.8, 128.5, 123.2, 115.7, 71.6, 71.4, 60.8, 60.6, 31.5, 14.3. HRMS $(E S I+): \mathrm{m} / z$ calcd for $\mathrm{C}_{44} \mathrm{H}_{51} \mathrm{BrNO}_{12}\left[\mathrm{M}+\mathrm{NH}_{4}\right]^{+}$: 864.2595; found: 864.2565 .

Calix[4]arene-tetraester-monoazide 6. Calix[4]arene-tetraestermonobromide 5 (1.29 g, $1.52 \mathrm{mmol}$ ), Cul (29 mg, $0.152 \mathrm{mmol}$ ), $\mathrm{NaN}_{3}(198$ $\mathrm{mg}, 3.05 \mathrm{mmol}$ ) and sodium ascorbate $(15 \mathrm{mg}, 0.076 \mathrm{mmol})$ were dried under vacuum and dissolved in degassed $\mathrm{EtOH} / \mathrm{H}_{2} \mathrm{O}$ mixture $(7: 3,7 \mathrm{~mL})$ under argon atmosphere. Trans- $N, N$-dimethylcyclohexane-1,2-diamine $(48 \mu \mathrm{L}, 0.304 \mathrm{mmol}$ ) was then added and the reaction mixture was stirred at reflux for $48 \mathrm{~h}$. Ethanol was evaporated under reduced pressure and the residue was diluted with deionized water $(10 \mathrm{~mL})$ and extracted with $\mathrm{CH}_{2} \mathrm{Cl}_{2}(3 \times 20 \mathrm{~mL})$. The combined organic phases were washed once with deionized water and concentrated under reduced pressure. The crude material was purified by column chromatography on silica $\left[\mathrm{CH}_{2} \mathrm{Cl}_{2} / \mathrm{MeOH}\right.$ (from 98:2 to $92: 8 \mathrm{v} / \mathrm{v}$ ratio)] to afford the desired product 6 as a yellow oil $\left(0.89 \mathrm{~g}, 72 \%\right.$ yield). IR (ATR) $v\left(\mathrm{~cm}^{-1}\right)=2109,1757,1736 .{ }^{1} \mathrm{H}$ NMR $(400$ $\left.\mathrm{MHz}, \mathrm{CDCl}_{3}, 298 \mathrm{~K}\right): \delta(\mathrm{ppm})=6.85-6.68(\mathrm{~m}, 7 \mathrm{H}, \mathrm{ArH}), 6.58\left(\mathrm{t},{ }^{3} \mathrm{~J}=7.2 \mathrm{~Hz}\right.$, $1 \mathrm{H}, \operatorname{ArH}), 6.51\left(\mathrm{~d},{ }^{3} \mathrm{~J}=7.2 \mathrm{~Hz}, 2 \mathrm{H}, \mathrm{ArH}\right), 6.08(\mathrm{~s}, 2 \mathrm{H}, \operatorname{ArH}), 4.88\left(\mathrm{~d},{ }^{2} \mathrm{~J}=14\right.$ $\mathrm{Hz}, 2 \mathrm{H}, \mathrm{ArCH}_{2} \mathrm{ax}$ ), $4.83\left(\mathrm{~d},{ }^{2} \mathrm{~J}=14 \mathrm{~Hz}, 2 \mathrm{H}, \operatorname{ArCH}_{2} \mathrm{ax}\right), 4.77$ (d, $2 \mathrm{H},{ }^{2} \mathrm{~J}=$ $\left.16.4 \mathrm{~Hz}, \mathrm{ArOCH}_{2} \mathrm{CO}\right), 4.70\left(\mathrm{~d}, 2 \mathrm{H},{ }^{2} \mathrm{~J}=16.4 \mathrm{~Hz}, \mathrm{ArOCH}_{2} \mathrm{CO}\right), 4.65(\mathrm{~s}, 4 \mathrm{H}$, ArOCH$\left.H_{2} \mathrm{CO}\right), 4.3-4.1\left(\mathrm{~m}, 8 \mathrm{H}, \mathrm{OCH}_{2} \mathrm{CH}_{3}\right), 3.25\left(\mathrm{~d},{ }^{2} \mathrm{~J}=14 \mathrm{~Hz}, 2 \mathrm{H}, \mathrm{ArCH}_{2} \mathrm{eq}\right)$ $3.20\left(\mathrm{~d},{ }^{2} \mathrm{~J}=14 \mathrm{~Hz}, 2 \mathrm{H}, \mathrm{ArCH}_{2} \mathrm{eq}\right), 1.37-1.18\left(\mathrm{~m}, 12 \mathrm{H}, \mathrm{OCH}_{2} \mathrm{CH}_{3}\right) .{ }^{13} \mathrm{C}$ $\mathrm{NMR}\left(100 \mathrm{MHz}, \mathrm{CDCl}_{3}, 298 \mathrm{~K}\right): \delta(\mathrm{ppm})=170.4,170.1,170.0,156.4,155.8$ 153.2, 136.2, 135.4, 134.7, 134.3, 134.0, 129.2, 128.9, 128.5, 123.1, 122.9 $118.8,71.6,71.5,71.3,60.8(2), 60.7(8), 60.6,31.7,31.5,14.3$. HRMS (ESI+): $\mathrm{m} / z$ calcd for $\mathrm{C}_{44} \mathrm{H}_{51} \mathrm{~N}_{4} \mathrm{O}_{12}\left[\mathrm{M}+\mathrm{NH}_{4}\right]^{+}:$827.3503; found: 827.3498 .

Calix[4]arene-tetraacid-monoazide 7. Calix[4]arene-tetraestermonoazide 6 (138 mg, $0.170 \mathrm{mmol}$ ) was dissolved in $10 \mathrm{~mL}$ of THF and an aqueous $\mathrm{NMe}_{4} \mathrm{OH}$ solution $(10 \%, 14 \mathrm{~mL})$ was added. The reaction mixture was stirred at reflux for 16 hours. The mixture was slowly brought to $\mathrm{pH} 1$ using $\mathrm{HCl}(4 \mathrm{M})$ and the THF was evaporated under reduced pressure. The aqueous phase was centrifuged and the precipitate was washed with water $(2 \times 10 \mathrm{~mL})$. The resulting solid was dried under vacuum to yield the desired compound 7 as a white solid $(115 \mathrm{mg}, 97 \%$ yield). $\mathrm{Mp}=194^{\circ} \mathrm{C} . \mathrm{IR}(\mathrm{NaCl}) \vee\left(\mathrm{cm}^{-1}\right)=2111,1741 .{ }^{1} \mathrm{H} \mathrm{NMR}(400 \mathrm{MHz}$, DMSO- $\left.d_{6}, 298 \mathrm{~K}\right): \delta(\mathrm{ppm})=11.5-13.0(\mathrm{~s}, 4 \mathrm{H}, \mathrm{COOH}), 7.01-6.89(\mathrm{~m}, 4 \mathrm{H}$, $\mathrm{ArH}), 6.80-6.57(\mathrm{~m}, 5 \mathrm{H}, \mathrm{ArH}), 6.45(\mathrm{~s}, 2 \mathrm{H}, \mathrm{ArH}), 4.85\left(\mathrm{~d},{ }^{2} \mathrm{~J}=13.2 \mathrm{~Hz}, 4 \mathrm{H}\right.$, $\left.\mathrm{ArCH}_{2} \mathrm{ax}\right), 4.71-4.54\left(\mathrm{~m}, 8 \mathrm{H}, \operatorname{ArOCH}_{2} \mathrm{CO}\right), 3.27(\mathrm{~d}, 2 \mathrm{~J}=13.2 \mathrm{~Hz}, 4 \mathrm{H}$ $\mathrm{ArCH}_{2}$ eq). ${ }^{13} \mathrm{C}$ NMR (100 MHz, DMSO-d, $\left.298 \mathrm{~K}\right): \delta(\mathrm{ppm})=171.0,155.4$,
136.2, 134.3, 128.9, 128.7, 128.3, 123.3, 118.7, 118.0, 71.4, 30.6. HRMS (ESI+): $\mathrm{m} / \mathrm{z}$ calcd for $\mathrm{C}_{36} \mathrm{H}_{32} \mathrm{~N}_{3} \mathrm{O}_{12}[\mathrm{M}+\mathrm{H}]^{+}: 698.1986$; found: 698.2041.

Calix[4]arene-tetraacid-monoamine 8. Triphenylphosphine $(0.32 \mathrm{~g}, 1.2$ $\mathrm{mmol}$ ) was added to a solution of calix[4]arene-tetraacid-monoazide 7 $(0563 \mathrm{~g}, 0.807 \mathrm{mmol})$ in a mixture of THF $(20 \mathrm{~mL})$ and water $(1 \mathrm{~mL})$. The mixture was stirred at reflux for $17 \mathrm{~h}$. After cooling to room temperature, the solution was concentrated under reduced pressure. The resulting yellow residue was dispersed in $\mathrm{CH}_{2} \mathrm{Cl}_{2}(10 \mathrm{~mL})$ and centrifuged. The precipitate was washed with methanol $(5 \mathrm{~mL}), \mathrm{CH}_{2} \mathrm{Cl}_{2}(3 \times 5 \mathrm{~mL})$ and dried under vacuum to yield product 8 as white solid $(0.393 \mathrm{~g}, 73 \%$ yield). The ${ }^{1} \mathrm{H}$ NMR spectrum of $\mathbf{8}$ is in accordance with the one reported in the literature. ${ }^{[28]}$

Calix[4]arene-tetraacid-monodiazonium tetrafluoroborate 1 Calix[4]arene-tetraacid-monoamine $8(10.0 \mathrm{mg}, 0.015 \mathrm{mmol})$ was dispersed in anhydrous $\mathrm{CH}_{3} \mathrm{CN}(0.5 \mathrm{~mL})$ and the reaction mixture was cooled to $-40^{\circ} \mathrm{C}$ under argon atmosphere. Nitrosonium tetrafluoroborate $(1.9 \mathrm{mg}, 0.016 \mathrm{mmol})$ was added and the mixture was stirred at $-40^{\circ} \mathrm{C}$ for 2 hours while being protected from light by an aluminium foil. The reaction mixture was carefully evaporated under reduced pressure at room temperature and the residue was washed with diethyl ether $(2 \times 1 \mathrm{~mL})$ affording product 1 as a white powder $(10.7 \mathrm{mg}, 93 \%$ yield). $\mathrm{IR}(\mathrm{KBr}) \vee(\mathrm{cm}$ $\left.{ }^{1}\right)=2938,2258,1753,1436,1194,1053 .{ }^{1} \mathrm{H}$ NMR $\left(300 \mathrm{MHz}, \mathrm{CD}_{3} \mathrm{CN}, 298\right.$ $\mathrm{K}): \delta(\mathrm{ppm})=7.95(\mathrm{~s}, 2 \mathrm{H}, \operatorname{ArH}), 7.05-6.70(\mathrm{~m}, 9 \mathrm{H}, \operatorname{ArH}), 5.14(\mathrm{~s}, 2 \mathrm{H}$, $\left.\mathrm{ArOCH}_{2} \mathrm{CO}\right), 5.06\left(\mathrm{~d},{ }^{2} \mathrm{~J}=14.1 \mathrm{~Hz}, 2 \mathrm{H}, \mathrm{ArCH}_{2} \mathrm{ax}\right), 4.75\left(\mathrm{~d},{ }^{2} \mathrm{~J}=16.2 \mathrm{~Hz}\right.$ $2 \mathrm{H}, \mathrm{ArOCH}_{2} \mathrm{CO}$ ), $4.65\left(\mathrm{~d},{ }^{2} \mathrm{~J}=13.5 \mathrm{~Hz}, 2 \mathrm{H}, \mathrm{ArCH}_{2} \mathrm{ax}\right), 4.64(\mathrm{~s}, 2 \mathrm{H}$, $\left.\mathrm{ArOCH}_{2} \mathrm{CO}\right), 4.62\left(\mathrm{~d},{ }^{2} \mathrm{~J}=16.2 \mathrm{~Hz}, 2 \mathrm{H}, \mathrm{ArOCH}_{2} \mathrm{CO}\right), 3.55\left(\mathrm{~d},{ }^{2} \mathrm{~J}=13.8 \mathrm{~Hz}\right.$ $2 \mathrm{H}, \mathrm{ArCH}_{2} \mathrm{eq}$ ), 3.37 (d, ${ }^{2} \mathrm{~J}=13.5 \mathrm{~Hz}, 2 \mathrm{H}, \mathrm{ArCH}_{2} \mathrm{eq}$ )

Electrochemical experiments. Electrochemical measurements were carried out using a conventional three-electrode setup consisting of a 3 $\mathrm{mm}$ diameter glassy carbon disk electrode (IJ Cambria) as working electrode, a saturated calomel electrode (SCE, Metrohm) as reference and a platinum foil as counter-electrode. The potentiostat was an Autolab PGSTAT 302N (Eco-Chemie B.V.). Prior to surface modification, the glassy carbon electrodes were polished successively with 1.0, 0.3 and $0.05 \mu \mathrm{m}$ alumina paste and thoroughly rinsed. All experiments were conducted under Ar blanket.

\section{Acknowledgements}

The ARC of the FWB, the ULB and the Région Wallonne (grant to A.M.) are acknowledged for financial support.

Keywords: Calixarenes • Diazonium salts • Electrodeposition • Copper Catalysis• Surface Chemistry

[1] J. J. Gooding, S. Ciampi, Chem. Soc. Rev. 2011, 40, 2704-2718.

[2] J. J. Gooding, Electroanalysis 2008, 20, 573-582.

[3] C. J. Love, L. A. Estroff, J. K. Kriebel, R. G. Nuzzo, G. M. Whitesides, Chem. Rev. 2005, 105, 1103-1169.

[4] C. Vericat, M. E. Vela, G. Benitez, P. Carro, R. C. Salvarezza, Chem Soc. Rev. 2010, 39, 1805-1834.

[5] (a) J. Pinson, F. Podvorica, Chem. Soc. Rev. 2005, 34, 429-439; b) S Mahouche-Chergui, S. Gam-Derouich, C. Mangeney, M. H. Chehimi, Chem. Soc. Rev. 2011, 40, 4143-4166.

[6] A. Adenier, C. Combellas, F. Kanoufi, J. Pinson, F. I. Podvorica, Chem Mater. 2006, 18, 2021-2029.

[7] A. Mattiuzzi, I. Jabin, C. Mangeney, C. Roux, O. Reinaud, L. Santos, J. Bergamini, P. Hapiot, C. Lagrost, Nat. Commun. 2012, 3, 1130. 
[8] It was shown that propyl groups are the smallest possible for blocking the oxygen-through-the-annulus rotation of the aromatic units, see: A Ikeda, S. Shinkai, Chem. Rev., 1997, 97, 1713-1734.

[9] P. Blond, A. Mattiuzzi, H. Valkenier, L. Troian-Gautier, J.-F. Bergamini, T. Doneux, E, Goormaghtigh, V. Raussens, I. Jabin, Langmuir 2018, 34 6021-6027.

[10] L. Troian-Gautier, D. Martinez-Tong, J. Hubert, F. Reniers, M. Sferrazza, A. Mattiuzzi, C. Lagrost, I. Jabin, J. Phys. Chem. C 2016, 120 22936-22945

[11] L. Troian-Gautier, H. Valkenier, A. Mattiuzzi, I. Jabin, N. Van den Brande, B. Van Mele, J. Hubert, F. Reniers, G. Bruylants, C. Lagrost, Y. Leroux, Chem. Commun. 2016, 52, 10493-10496.

[12] L. Santos, A. Mattiuzzi, I. Jabin, N. Vandencasteele, F. Reniers, O. Reinaud, P. Hapiot, S. Lhenry, Y. Leroux, C. Lagrost, J. Phys. Chem. C 2014, 118, 15919-15928.

[13] H. Valkenier, V. Malytskyi, P. Blond, M. Retout, A. Mattiuzzi, J. Goole, V. Raussens, I. Jabin, G. Bruylants, Langmuir 2017, 33, 8253-8259.

[14] (a) G. De Leener, F. Evoung-Evoung, A. Lascaux, J. Mertens, A. G Porras-Gutierrez, N. Le Poul, C. Lagrost, D. Over, Y. R. Leroux, F. Reniers, P. Hapiot, Y. Le Mest, I. Jabin, O. Reinaud, J. Am. Chem. Soc 2016, 138, 12841-12853; (b) J. P. Buttress, D. P. Day, J. M. Courtney, E. J. Lawrence, D. L. Hughes, R. J. Blagg, A. Crossley, S. E. Matthews C. Redshaw, P. C. Bulman Page, G. G. Wildgoose, Langmuir 2016, 32 7806-7813; (c) C. Jiang, S. Moraes Silva, S. Fan, Y. Wu, M. Tanzirul Alam, G. Liu, J. J. Gooding, J. Electroanal. Chem. 2017, 785, 265-278; (d) T. Breton, A. J. Downard, Aust. J. Chem. 2017, 70, 960-972.

[15] C. Cannizzo, M. Wagner, J.-P. Jasmin, C. Vautrin, D. Doizi, C. Lamouroux, A. Chaussé, Tetrahedron Lett. 2014, 55, 4315-4318.
[16] For seminal work, see: (a) J.-D. van Loon, A. Arduini, W. Verboom, R Ungaro, G. J. van Hummel, S. Harkema, D. N. Reinhoudt, Tetrahedron Lett. 1989, 30, 2681-2684; (b) C. D. Gutsche, L.-G. Lin, Tetrahedron 1986, 42, 1633-1640.

[17] R. Lavendomme, S. Zahim, G. De Leener, A. Inthasot, A. Mattiuzzi, M. Luhmer, O. Reinaud, I. Jabin, Asian J. Org. Chem. 2015, 4, 710-722.

[18] H. Shimizu, K. Iwamoto, K. Fujimoto, S. Shinkai, Chem. Lett. 1991, 2147.

[19] The term "iteroselectivity" refers to the selectivity that concerns the formation of products (i.e. iteromers) differing by the number of repeating chemical transformations they underwent. See: R. Lavendomme, A Leroy, M. Luhmer, I. Jabin, J. Org. Chem. 2014, 79, 6563-6570.

[20] X. Chen, M. Ji, D. R. Fisher, C. M. Wai, Synlett 1999, 11, 1784-1786.

[21] Note that the formation of oxidized products under nitration conditions was already reported on a related calix[4]arene, see: P. Timmerman, S Harkema, G. J. van Hummel, W. Verboom, D. N. Reinhoudt, J. Incl. Phenom. Mol. Recognit. Chem. 1993, 16, 189-197.

[22] J. Andersen, U. Madsen, F. Björkling, X. Liang, Synlett 2005, 14, 2209 2213.

[23] C. Jaime, J. De Mendoza, P. Prados, P. M. Nieto, C. Sanchez, J. Org Chem., 1991, 56, 3372-3376.

[24] For a recent example, see: A. Inthasot, E. Brunetti, M. Lejeune, N Ménard, T. Prangé, L. Fusaro, G. Bruylants, O. Reinaud, M. Luhmer, I. Jabin, B. Colasson, Chem. Eur. J. 2016, 22, 4855-4862.

[25] J. Pinson, D. Bélanger, Chem. Soc. Rev. 2011, 40, 3995-4048.

[26] S. H. DuVall, R. L. McCreery, Anal. Chem. 1999, 71, 4594-4602

[27] H. Kawabata, M. Aoki, K. Murata, S. Shinkai, Supramol. Chem. 1993, 2, 33-39.

[28] X. Chen, M. Ji, D. R. Fisher, C. M. Wai, Synlett 1999, 11, 1784-1786. 


\section{FULL PAPER}

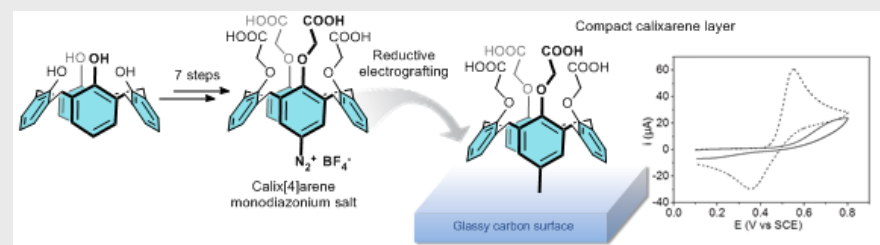

The efficient synthesis of a calix[4]arene-monodiazonium salt is described. The electrografting of this new compound on glassy carbon electrodes leads to a compact covalently-bound calix[4]arene layer.

\section{Surface Functionalization}

Volodymyr Malytskyi, ${ }^{[a]}$ Ludovic TroianGautier, ${ }^{[a]}$ Alice Mattiuzzi, ${ }^{[a]},{ }^{[b]}$ Sarah Lambotte, ${ }^{[a]}$ Benedetta Cornelio, ${ }^{\text {a] }}$ Corinne Lagrost, ${ }^{*[c]}$ and Ivan Jabin ${ }^{*[a]}$

Page No. 1 - Page No. 6

Synthesis of a Calix[4]arenemonodiazonium Salt for Surface Modification 